DOI: $10.19195 / 2084-5065.48 .9$

\title{
Kryminalizacja pośrednictwa ubezpieczeniowego w prawie karnym gospodarczym
}

\author{
PIOTR OCHMAN
}

ORCID: 0000-0001-5590-3299

Katedra Kryminologii i Nauk o Bezpieczeństwie

Wydział Prawa, Administracji i Ekonomii Uniwersytetu Wrocławskiego

\section{SEBASTIAN SOLECKI}

Katedra Kryminologii i Nauk o Bezpieczeństwie

Wydział Prawa, Administracji i Ekonomii Uniwersytetu Wrocławskiego

\section{Uwagi ogólne}

Pośrednictwo ubezpieczeniowe stanowi aktualnie jeden z podstawowych kanałów dystrybucji produktów ubezpieczeniowych obok sprzedaży bezpośredniej czy też coraz bardziej popularnego bancassurance ${ }^{1}$. W 2016 roku pośrednicy ubezpieczeniowi odpowiadali za ponad 75\%

1 J. Łańcucki, Przesłanki i kierunki zmian $w$ regulacjach dotyczących pośrednictwa ubezpieczeniowego, „Prace Naukowe Uniwersytetu Ekonomicznego we Wrocławiu” 228,2011 , s. 258-267. 
wartości składki przypisanej brutto ${ }^{2}$ towarzystw ubezpieczeniowych ${ }^{3}$. Udział poszczególnych kanałów dystrybucji w wypadku ubezpieczeń na życie ${ }^{4}$ wynosił odpowiednio: kanał sprzedaży bezpośredniej — 32,5\% przypisu składki ${ }^{5}$, agenci ubezpieczeniowi - 64,3\% przypisu składki, brokerzy - 3\% przypisu składki oraz $0,11 \%$ pozostałe kanały dystrybucji. Również w odniesieniu do pozostałych ubezpieczeń osobowych oraz ubezpieczeń majątkowych ${ }^{6}$ udział agentów ubezpieczeniowych wynosił $65 \%$ przypisu składki, brokerzy 17,6\% przypisu składki, sprzedaż bezpośrednia 10,4\% przypisu składki oraz 7,1\% przypisu składki w odniesieniu do innych kanałów dystrybucji.

Pośrednictwo ubezpieczeniowe stanowi również jeden z podstawowych filarów rynkowo zorientowanej organizacji ubezpieczeń gospodarczych ${ }^{7}$. Funkcjonowanie tego sektora rynku ubezpieczeniowego jest bowiem immanentnie związane $\mathrm{z}$ potrzebami zakładów ubezpieczeń, polegającymi zwłaszcza na efektywnej dystrybucji oferowanych przez nie produktów. Pośrednictwo ubezpieczeniowe stanowi przeto kluczowy

2 Czyli kwoty składek brutto należne z tytułu zawartych w danym okresie sprawozdawczym umów ubezpieczenia, niezależnie od tego, czy kwoty te opłacono.

3 Agenci ubezpieczeniowi odpowiadali za łączny przypis na poziomie ponad 36016829 tys. zł (dział I oraz dział II), natomiast brokerzy za 6320751 tys. zł (dział I oraz dział II) z łącznej kwoty zebranej przez rynek w 2016 roku, wynoszącej odpowiednio 55684646 tys. zł. Biuletyn informacyjny. Rynek ubezpieczeń 2016, https://www.knf. gov.pl/?articleId=58844\&p_id=18 (dostęp: 3.06.2018).

4 Dział I załącznika do ustawy z dnia 11 września 2015 r. o działalności ubezpieczeniowej i reasekuracyjnej (Dz.U. z 2018 r. poz. 999, z późn. zm.; dalej „ustawa o działalności ubezpieczeniowej”).

5 Znaczna część udziału kanału sprzedaży bezpośredniej w przypisie składki w dziale I była związana z ubezpieczeniami grupowymi. W ubezpieczeniach grupowych łączny przypis składki w 2016 roku wynosił 8135001 tys. zł, z czego 4903138 tys. zł przypadło na kanał sprzedaży bezpośredniej, 2501813 tys. zł na agentów ubezpieczeniowych oraz 705305 tys. zł na kanał dystrybucji brokerskiej.

6 Dział II załącznika do ustawy o działalności ubezpieczeniowej.

7 Ubezpieczenia w gospodarce rynkowej 1, red. A. Wąsiewicz, Bydgoszcz 1994, s. 106; Podstawy ubezpieczeń, t. 1. Mechanizmy i funkcje, red. J. Monkiewicz, Warszawa 2000, s. 90-91; T. Sangowski, Ubezpieczenia gospodarcze, Warszawa 1998, s. 112-115; W. Ronka-Chmielowiec, Ubezpieczenia. Rynek i ryzyko, Warszawa 2002, s. 97-98; M. Kaczała, [w:] Pośrednictwo finansowe w Polsce, red. W. Przybylska-Kapuścińska, Warszawa 2009, s. 244 n.; E. Kowalewski, Aspekty prawne pośrednictwa ubezpieczeniowego, [w:] Przemiany polskiego prawa, t. 2, red. E. Kustra, Toruń 2002, s. 65-66. 
kanał w tym zakresie, a przy tym pełni także istotne funkcję ekonomiczne i społeczne ${ }^{8}$. Pośrednicy ubezpieczeniowi - odgrywając główną rolę w dystrybucji produktów ubezpieczeniowych — rozpowszechniają wiedzę i zapotrzebowanie klientów na te produkty, zwłaszcza poprzez podnoszenie ich świadomości oraz informowanie o zagrożeniach przyczyniają się do zmniejszenia asymetrii informacyjnej, a także pełnią funkcję wzajemnie uwiarygodniającą strony umowy ubezpieczenia ${ }^{9}$. Pośrednik ubezpieczeniowy występuje bowiem na styku sfery profesjonalnych podmiotów rynku ubezpieczeniowego (towarzystwa ubezpieczeniowe) z potencjalnymi konsumentami oferowanych przez nie usług. Regulacje prawne i etyczne odnoszące się do funkcjonowania pośrednictwa na rynku ubezpieczeniowym mają kluczowe znaczenie w procesie ochrony pozycji klienta $\mathrm{w}$ świetle istniejącej asymetrii informacyjnej ${ }^{10}$. Z kolei sposób działania instytucji pośrednictwa ubezpieczeniowego, a także ich rola w alokacji składki stanowi jeden z wyznaczników stabilności rynku ubezpieczeniowego ${ }^{11}$.

Przedmiotem artykułu jest analiza przepisów karnych kryminalizujących pośrednictwo ubezpieczeniowe w Polsce $\mathrm{w}$ przededniu wejścia $\mathrm{w}$ życie nowej ustawy o dystrybucji ubezpieczeń ${ }^{12}$. Jest to zagadnienie plasujące się $\mathrm{w}$ ramach rozważań dogmatycznych prawa karnego go-

8 Por. I. Jędrzejczyk, J.W. Przybytniowski, Pośrednictwo ubezpieczeniowe w polskim obszarze Jednolitego Rynku Europejskiego, ,Zeszyty Naukowe SGGW w Warszawie. Polityki Europejskie, Finanse i Marketing” 2009, nr 2, s. 173 n.

9 W. Ronka-Chmielowiec, Ubezpieczenia, Warszawa 2016, s. 127-128.

10 M. Kaczała, op. cit., s. 278-279; R. Kurek, Asymetria informacji na rynku ubezpieczeniowym, „Prace Naukowe Uniwersytetu Ekonomicznego we Wrocławiu” 245, 2012, s. 280-281. Warto także zwrócić uwagę, że w motywie 6 preambuły dyrektywy Parlamentu Europejskiego i Rady (UE) 2016/97 w sprawie dystrybucji ubezpieczeń (Dz. Urz. UE seria L, Nr 26 z 2 lutego 2016 r., s. 19; dalej „IDD” lub „dyrektywą w sprawie dystrybucji ubezpieczeń”) wskazano: „Konsumenci powinni korzystać z ochrony na jednakowym poziomie niezależnie od różnic między kanałami dystrybucji. Dla zagwarantowania jednakowego poziomu ochrony oraz umożliwienia konsumentowi korzystania z porównywalnych standardów, zwłaszcza w zakresie ujawniania informacji, zasadnicze znaczenie mają równe warunki prowadzenia działalności przez dystrybutorów”.

11 R. Pacud, G. Mikś, Tajemnica zawodowa w pośrednictwie ubezpieczeniowym. Zakres i rodzaje ochrony (cz. I), ,Monitor Prawniczy” 2015, nr 11, s. 610.

12 Ustawa z dnia 15 grudnia 2017 r., Dz.U. z 2017 poz. 2486, z późn. zm.; dalej „DUU” lub „ustawa o dystrybucji ubezpieczeń”. 
spodarczego w aspekcie ochrony statyki obrotu gospodarczego, tj. jego podstawowych struktur i instytucji ${ }^{13}$. Zaprezentowana zostanie ewolucja kryminalizacji tego sektora rynku ubezpieczeniowego, geneza aktualnej regulacji karnoprawnej, a także uwagi krytyczne do najnowszych przepisów karnych ustawy o dystrybucji ubezpieczeń. Dokonana analiza będzie stanowić podstawę przedstawienia uwag de lege lata oraz propozycji de lege ferenda.

\section{Zarys ewolucji prawnej regulacji pośrednictwa ubezpieczeniowego w Polsce}

Problematyka prawnej regulacji pośrednictwa ubezpieczeniowego stanowi przedmiot dyskusji praktyków i teoretyków rynku ubezpieczeniowego od momentu odzyskania przez Polskę niepodległości ${ }^{14}$. Pierwsze regulacje prawne odnoszące się do agentów ubezpieczeniowych pojawiły się bowiem już w rozporządzeniu Prezydenta RP z dnia 24 lutego 1928 r. o kontroli ubezpieczeń ${ }^{15}$. Przepis art. 101 tego rozporządzenia kryminalizował zawieranie umowy ubezpieczenia lub pośredniczenie w zawarciu takiej umowy w imieniu zakładu ubezpieczeń, bez zezwolenia na działalność tego rodzaju, pod groźbą kary aresztu do 6 miesięcy lub karny grzywny do 10 tys. złotych ${ }^{16}$.

Wraz z wejściem w życie rozporządzenia Prezydenta RP z dnia 24 października 1934 r. o pośrednictwie ubezpieczeniowem w polskim systemie prawnym pojawiła się pierwsza definicja legalna pośrednictwa ubezpieczeniowego. Zgodnie z przepisem art. 1 ust. 1 tego rozporządzenia ,za pośredniczenie ubezpieczeniowe uważa się: 1) zawieranie za wynagrodzeniem umów ubezpieczenia w imieniu zakładu ubezpieczeń, 2) pośredniczenie za wynagrodzeniem w zawieraniu umów ubezpieczenia"17. W przepisie art. 18 rozporządzenia stypizowane zostało wykro-

13 Zob. S. Żółtek, Prawo karne gospodarcze w aspekcie zasady subsydiarności, Warszawa 2009, s. 39-40.

14 Zob. Ubezpieczenia $w$ gospodarce rynkowej..., s. 106-107 i cytowana tam literatura.

15 Dz.U. z 1928 r. Nr 9, poz. 64.

16 Szerzej zob. Ubezpieczenia w gospodarce rynkowej..., s. 107.

17 Dz.U. z 1934 r., poz. 834. 
czenie, którego sprawcą mógł być członek władzy zakładu ubezpieczeń niearealizujący obowiązku zgłoszenia ajenta do rejestru albo korzystający z usług pośrednika, który nie posiada stosownych uprawnień. W art. 18 ust. 2 pkt 1 przewidziano odpowiedzialność ajenta ubezpieczeniowego za niezgłoszenie pomocnika do wykazu zgodnie z art. 9 ust. 1 rozporządzenia. Natomiast w art. 18 ust. 2 pkt 2 stypizowano wykroczenie polegające na wykonywaniu zawodu maklera ubezpieczeniowego bez zezwolenia władzy. Wszystkie te czyny zabronione zagrożone były karą grzywny do 3000 zł. Cytowane rozporządzenie formalnie obowiązywało do 1952 roku.

W dniu 28 marca 1952 roku uchwalono nową ustawę o ubezpieczeniach państwowych ${ }^{18}$, która jednak całkowicie pomijała problematykę pośrednictwa ubezpieczeniowego. Prawna regulacja w tym zakresie pojawiła się ponownie wraz z wejściem w życie ustawy z dnia 2 grudnia 1958 r. o ubezpieczeniach majątkowych i osobowych ${ }^{19}$. Nie stypizowano w niej jednak odrębnych czynów zabronionych w zakresie pośrednictwa ubezpieczeniowego. Ponadto w schyłkowym okresie ustroju socjalistycznego ustawodawca zdecydował o rezygnacji z pośrednictwa ubezpieczeniowego jako formy instytucji ustawowej, ustawa z dnia 20 września 1984 roku o ubezpieczeniach majątkowych i osobowych nie zawierała bowiem regulacji dotyczących wskazanej materii ${ }^{20}$. Dopiero przemiany społeczno-gospodarcze przełomu lat 80. i 90. ubiegłego stulecia i demonopolizacja rynku ubezpieczeniowego przyniosły kolejne zmiany w kwestii pośrednictwa w tym zakresie. Prawną podstawą funkcjonowania podmiotów pośredniczących był przepis art. 34 ust. 1 ustawy z dnia 28 lipca 1990 r. o działalności ubezpieczeniowej ${ }^{21}$. W literaturze przedmiotu regulacja ta oceniana była jednak jako fragmentaryczna i niespełniająca wymogów nowoczesnego rynku ubezpieczeniowego ${ }^{22}$. Środkiem zaradczym wobec tego stanu rzeczy miała być jej nowelizacja ${ }^{23}$. Ustalo-

18 Dz.U. z 1952 r. Nr 20, poz. 130.

19 Dz.U. z 1958 r. Nr 72, poz. 357.

20 Dz.U. z 1984 r. Nr 45, poz. 242.

21 Dz.U. z 1990 r. Nr 59, poz. 344.

22 Por. E. Kowalewski, op. cit., s. 107-108.

23 Ustawą z 8 czerwca 1995 r. o zmianie ustawy o działalności ubezpieczeniowej, o zmianie rozporządzanie Prezydenta Rzeczypospolitej — Kodeks handlowy oraz 
ny w 1995 roku kształt prawnej regulacji pośrednictwa ubezpieczeniowego, pomimo podnoszonych w literaturze mankamentów ${ }^{24}$, przetrwał zasadniczo do roku $2003^{25}$. Dopiero w przededniu akcesji Polski do Unii Europejskiej została uchwalona, w dniu 22 maja 2003 roku, zupełnie nowa ustawa o pośrednictwie ubezpieczeniowym ${ }^{26}$. Przyjęcie tej ustawy przesądziło o przyjęciu koncepcji kompleksowej regulacji instytucji pośrednictwa ubezpieczeniowego w odrębnym akcie prawnym ${ }^{27}$. Akt ten, będący elementem pakietu ustaw regulujących rynek ubezpieczeniowy, implementował częściowo do polskiego porządku prawnego dyrektywę 2002/92/WE z 30 września 2002 r. w sprawie pośrednictwa ubezpieczeniowego ${ }^{28}$. W uzasadnieniu rządowego projektu ustawy wskazywano, iż dotychczasowy stan prawny w zakresie pośrednictwa ubezpieczeniowego był regulacją fragmentaryczną, cechującą się zbyt daleko idącym rygoryzmem i niejasnościami, projektowana ustawa natomiast wychodzi „,naprzeciw potrzebie kompleksowego i nowoczesnego uregulowania

o zmianie ustawy o podatku dochodowym od osób prawnych (Dz.U. z 1995 r. Nr 96, poz. 478). Zob. szerzej R. Fulneczek, Pośrednictwo ubezpieczeniowe w świetle noweli do ustawy o działalności ubezpieczeniowej, „Prawo Asekuracyjne” 1995, nr 4, s. 57.

${ }^{24}$ Związane były one z problemami w zakresie systemu licencjonowania agentów, brakiem centralnego rejestru agentów, sprzecznością z przepisami Unii Europejskiej, a nawet kwestiami techniczno-legislacyjnymi (zob. szerzej A. Chróścicki, Pośrednictwo ubezpieczeniowe i finansowe. Komentarz, Warszawa 2008, s. 11-12; J. Łopuski, E. Kowalewski, Założenia legislacyjne dalszej reformy prawa ubezpieczeniowego, „Państwo i Prawo" 1991, nr 11, s. 15-18).

25 Prace nad reformą prawa ubezpieczeniowego ruszyły już w 1992 roku, kiedy to z inicjatywy PIU rozpoczęto opracowywanie tzw. pakietu ustaw ubezpieczeniowych. Efektem prac legislacyjnych było uchwalenie w dniu 23 sierpnia 2001 roku ustawy o działalności ubezpieczeniowej oraz ustawy o pośrednictwie ubezpieczeniowym, które jednak zostały zawetowane przez Prezydenta RP w dniu 10 września 2001 roku. Pomimo prezydenckiego weta część proponowanych regulacji znalazła się w nowych ustawach przyjętych w 2003 roku (zob. E. Kowalewski, op. cit., s. 70-72).

${ }^{26}$ Dz.U. z 2003 r. Nr 124, poz. 1154; dalej „PUU” lub „ustawa o pośrednictwie ubezpieczeniowym".

27 A. Wąsiewicz, Koncepcja legislacyjna przebudowy systemu prawa ubezpieczeń gospodarczych, „Prawo Asekuracyjne” 1997, nr 3, s. 17-20.

28 Dz.Urz. WE seria L, Nr 9 z 15 stycznia 2003 r., s. 3; dalej „dyrektywa 2002/92/ WE". Zob. także E. Wieczorek, [w:] Prawo ubezpieczeń gospodarczych. Komentarz, t. 1, red. Z. Brodecki, M. Serwach, M. Glicz, Warszawa 2010, s. 1096-1097. 
pośrednictwa ubezpieczeniowego"29. Warto zwrócić uwagę na fakt, że akcesja Polski do Unii Europejskiej spowodowała, że polski rynek ubezpieczeniowy stał się częścią składową tak zwanego jednolitego rynku ubezpieczeniowego Unii Europejskiej ${ }^{30}$. Ustawa o pośrednictwie ubezpieczeniowym zawiera dwa przepisy karne kryminalizujące bezprawne wykonywanie czynności pośrednictwa ubezpieczeniowego (art. 47 ust. 1 i 2) oraz bezprawne posługiwanie się nazwami zastrzeżonymi dla pośredników ubezpieczeniowych (art. 48 ust. 1 i 2$)^{31}$.

Aktualnie następuje wdrożenie kolejnych, szerokich zmian odnoszących się do prawnej regulacji pośrednictwa ubezpieczeniowego w Polsce. Są one rezultatem przyjętej w dniu 20 stycznia 2016 r. dyrektywy 2016/97 w sprawie dystrybucji ubezpieczeń ${ }^{32}$. Motywem podjęcia prac legislacyjnych $\mathrm{w}$ zakresie pośrednictwa ubezpieczeniowego były w szczególności liczne mankamenty związane z funkcjonowaniem dyrektywy 2002/92/WE, konieczność doprecyzowania jej przepisów, potrzeba harmonizacji krajowych przepisów dotyczących dystrybucji ubezpieczeń i reasekuracji, a także wzmocnienie ochrony konsumentów ${ }^{33}$. Konsekwencją wejścia w życie IDD była konieczność implementacji jej postanowień do krajowego porządku prawnego ${ }^{34}$. Początkowo, dostoso-

29 Rządowy projekt ustawy o pośrednictwie ubezpieczeniowym, druk sejmowy nr 585.

30 Zob. szerzej Jednolity Rynek Ubezpieczeń w Unii Europejskiej. Procesy rozwoju i integracji, red. J. Monkiewicz, Bydgoszcz 2005, s. 45-81; W. Baranowska-Zając, Działalność ubezpieczeniowa w Polsce po implementacji dyrektywy Solvency II. Problematyka prawna, Warszawa 2017, s. 25-39.

31 Takie posunięcie legislacyjne stanowiło realizację dyrektywy 2002/92/WE w zakresie zapewnienia stosownych sankcji z tytułu wykonywania pośrednictwa ubezpieczeniowego bez zezwolenia. Zob. także K. Przewalska, M. Orlicki, Nowe prawo ubezpieczeń gospodarczych. Pakiet ustaw ubezpieczeniowych. Kodeks cywilny po zmianach, Bydgoszcz-Warszawa-Poznań 2004, s. 390.

32 Dz.Urz. UE seria L, nr 26 z 2.02.2016, s. 19; dalej „IDD”.

33 Szerzej M. Marszelewski, P. Piątkowski, Wpływ dyrektywy w sprawie dystrybucji ubezpieczeń na krajowy rynek pośrednictwa ubezpieczeniowego. Zagadnienia wybrane, „Studia Iuridica Toruniensia” 19, 2016, s. 111-135.

34 Ustawa o dystrybucji ubezpieczeń implementuje także dyrektywę Parlamentu Europejskiego i Rady 2014/65/UE z dnia 15 maja 2014 r. w sprawie rynków instrumentów finansowych oraz zmieniającą dyrektywę 2002/92/WE i dyrektywę 2011/61/UE (Dz. Urz. UE seria L, Nr 173 z 12.06.2014, s. 349, z późn. zm.). 
wanie ustawodawstwa krajowego miało nastąpić nie później niż 23 lutego 2018 roku. Efektem takiego stanu rzeczy było uchwalenie w dniu 15 grudnia 2017 r. ustawy o dystrybucji ubezpieczeń. Zgodnie z terminem implementacji, narzuconym przez IDD, tekst pierwotny przepisu art. 112 DUU zakładał jej wejście w życie z dniem 23 lutego 2018 roku. Jednakże, w konsekwencji wniosku Komisji Europejskiej, zakładającego odroczenie terminu stosowania IDD do dnia 1 października 2018 r. ${ }^{35}$, ustawą z dnia 26 stycznia 2018 r. o zmianie ustawy o dystrybucji ubezpieczeń $^{36}$ termin wejścia w życie DUU został przesunięty na 1 października $2018 \mathrm{roku}^{37}$. Z uwagi na nieodległy termin wejścia w życie ustawy o dystrybucji ubezpieczeń przedmiotem dalszych rozważań będą jej przepisy karne.

\section{Analiza ustawowych znamion przestępstw z ustawy o dystrybucji ubezpieczeń}

a. Lokalizacja i struktura przepisów karnych

Rozdział 7 ustawy o dystrybucji ubezpieczeń (art. 89-90) został poświęcony przepisom karnym. Zostały w nim zlokalizowane przestępstwa bezprawnego wykonywania działalności w zakresie dystrybucji ubezpieczeń (art. 89) oraz bezprawnego używania określeń zastrzeżonych na rzecz dystrybutora ubezpieczeń (art. 90). Prima facie stanowią one niemal dosłowne powtórzenie przepisów karnych art. 47 i 48 ustawy o pośrednictwie ubezpieczeniowym. Niemniej jednak warto zwrócić uwagę na występujące w tym zakresie różnice, a ponadto — ze względu na ich blankietowych charakter - ustalić, czy faktycznie, pomimo prawie niezmiennych dyspozycji prawnokarnych, zakres kryminalizacji nie uległ zmianie poprzez modyfikacje pozakarnych przepisów odniesienia. Niestety z całą pewnością wskazówką nie będzie w tym zakresie lektu-

35 Zob. szerzej uzasadnienie rządowego projektu ustawy o zmianie ustawy o dystrybucji ubezpieczeń, druk sejmowy nr 2207.

36 Dz.U. 2018 poz. 378.

37 W zakresie wejścia w życie poszczególnych jednostek artykułowych ustawy o dystrybucji ubezpieczeń zob. przepis art. 112 DUU. 
ra uzasadnienia rządowego projektu ustawy o dystrybucji ubezpieczeń, w którym to brakuje jakichkolwiek motywów wprowadzenia przepisów karnych $^{38}$.

\section{b. Dobro prawnie chronione}

Zlokalizowane w ustawie o dystrybucji ubezpieczeń przepisy karne chronią stabilność i bezpieczeństwo sektora ubezpieczeniowego, jak również zaufanie do niego, w tym także do dystrybutorów ubezpieczeń. Niewątpliwie przepisy te określają przestępstwa skierowane przeciwko zaufaniu do określonych instytucji i profesji, na którym ich działanie w znacznej mierze się opiera ${ }^{39}$.

\section{c. Podmioty odpowiedzialności karnej}

Przepisy karne ustawy o dystrybucji ubezpieczeń prima facie typizują przestępstwa powszechne ${ }^{40}$. Jednakże takie pierwsze wrażenie może

38 Podobny stan rzeczy występował zresztą na gruncie uzasadnienia rządowego projektu ustawy o pośrednictwie ubezpieczeniowym, gdzie tylko lakonicznie wskazano: „Rozdział 5 zawiera przepisy karne przewidujące sankcje w stosunku do podmiotów, które bezprawnie wykonują działalność pośrednictwa ubezpieczeniowego lub, nie będąc pośrednikiem ubezpieczeniowym, używają do określenia zakresu własnej działalności lub w reklamie oznaczeń wskazujących na działalność agencyjną lub brokerską" (Uzasadnienie rządowego projektu ustawy o pośrednictwie ubezpieczeniowym, druk sejmowy nr 585, s. 37-38).

39 E. Hryniewicz, [w:] Prawo karne gospodarcze, t. 10, red. R. Zawłocki, Warszawa 2012, s. 319-320. Zob. także O. Górniok, Prawo karne gospodarcze, Warszawa 1997, s. 211; Z. Sienkiewicz, [w:] Prawo karne gospodarcze, red. O. Górniok, Warszawa 2003, s. 502.

40 Oczywiście błędny i nieuzasadniony jest pogląd, że odpowiedzialność karna z tytułu przestępstwa z art. 47 PUU (obecnie 89 DUU) ,dotyczy osób fizycznych, prawnych oraz jednostek organizacyjnych nieposiadających osobowości prawnej” (tak J. Skorupka, [w:] System prawa karnego, t. 11. Szczególne dziedziny prawa karnego. Prawo karne wojskowe, skarbowe i pozakodeksowe, red. M. Bojarski, Warszawa 2018, s. 640). Pomijając już fakt, że odpowiedzialności karnej sensu stricto podlegać może wyłącznie osoba fizyczna, w odniesieniu do przestępstw z ustawy o pośrednictwie ubezpieczeniowym, a także ustawy o dystrybucji ubezpieczeń, ustawodawca nie przewidział konstrukcji odpowiedzialności podmiotów zbiorowych. 
zostać zachwiane przez zidentyfikowanie w ich obrębie tak zwanych klauzul odpowiedzialności zastępczej (klauzul odpowiedzialności karnej reprezentanta podmiotu zbiorowego $)^{41}$, które występują w przepisach art. 89 ust. 2 i 90 ust. 2 DUU. Przewidują one odpowiedzialność karną wobec dopuszczającego się czynów określonych odpowiednio w art. 89 ust. 1 pkt 1 i 3 DUU lub w art. 90 ust. 1 DUU, działającego w imieniu osoby prawnej ${ }^{42}$. Uwagi krytyczne odnośnie do tych konstrukcji w ustawodawstwie rynku ubezpieczeniowego zgłaszane były już kilkanaście lat temu ${ }^{43}$, dlatego też ponownie można zadać pytanie o konieczność i celowość wprowadzenia tych klauzul do ustawy o dystrybucji ubezpieczeń. Po pierwsze, dlaczego ustawodawca zdecydował się na „rozszerzenie” zakresu odpowiedzialności karnej wyłącznie na działania podejmowane w imieniu osoby prawnej? Wszak brak jakiegokolwiek uzasadnienia wyłączenia z kręgu podmiotowego jednostek organizacyjnych nieposiadających osobowości prawnej, którym ustawa przyznaje zdolność prawną, a nawet innych osób fizycznych. Aktualne brzmienie wskazanych przepisów powoduje, że de lege lata podejmowanie aktywności wskazanych w art. 89 ust. 1 pkt 1 i 3 lub 90 ust. 1 DUU w imieniu innych osób fizycznych lub jednostek organizacyjnych nieposiadających osobowości prawnej pozostanie niekaralne. Po drugie, dlaczego zrezygnowano z pojawiającej się w podobnych klauzulach, występujących na gruncie przepisów karnych innych ustaw rynku finansowego ${ }^{44}$, przesłanki działania w interesie innego podmiotu? Po trzecie wreszcie, czy faktycznie, jeśli

${ }^{41}$ Zob. szerzej P. Ochman, Karnoprawna ochrona podejmowania działalności finansowej, ,Ruch Prawniczy, Ekonomiczny i Socjologiczny” 2016, nr 2, s. 165-167.

42 Tożsame klauzule występowały na gruncie przepisów karnych ustawy o pośrednictwie ubezpieczeniowym (art. 47 ust. 2 i 48 ust. 2). Dlatego oczywiście błędny jest wniosek, jakoby poszerzały one „krąg podmiotów sprawczych na osoby działające $\mathrm{w}$ imieniu lub w interesie osoby fizycznej, osoby prawnej lub jednostki organizacyjnej nieposiadającej osobowości prawnej" (tak J. Skorupka, [w:] System prawa karnego, t. 11..., s. 638). Literalne brzmienie przepisów art. 47 ust. 2 i 48 ust. 2 ustawy o pośrednictwie ubezpieczeniowym od czasu jej uchwalenia się nie zmieniło i przewidywało „dodatkową" karalność wyłącznie wobec osób działających w imieniu osoby prawnej.

43 Zob. przykładowo J. Majewski, Komentarz do przepisów karnych nowej ustawy o działalności ubezpieczeniowej, „Kwartalnik Prawa Publicznego” 2003, nr 2, s. 185186; O. Górniok, op. cit., s. 212; Z. Sienkiewicz, op. cit., s. 505.

44 Zob. na przykład art. 99 ust. 3 ustawy z dnia 29 lipca 2005 r. o ofercie publicznej i warunkach wprowadzania instrumentów finansowych do zorganizowanego systemu 
wziąć pod uwagę aktualne zasady odpowiedzialności karnej za czyny podejmowane za kogoś innego, brakuje podstaw karania — w przypadku braku takich klauzul — za czyny podejmowane przez osobę fizyczną w imieniu innego podmiotu? ${ }^{45}$

$\mathrm{Na}$ marginesie warto również zwrócić uwagę na brak możliwości karania podmiotu zbiorowego w przypadku stwierdzenia faktu popełnienia przestępstw $z$ ustawy o dystrybucji ubezpieczeń przez jego reprezen$\operatorname{tanta}^{46}$. Jest to błąd powielony z ustawy o pośrednictwie ubezpieczeniowym, w której również brakowało takich podstaw. Taki stan rzeczy może dziwić, zwłaszcza że w treści innych ustaw kryminalizujących wybrane segmenty rynku finansowego możliwość taka występuje ${ }^{47}$.

\section{d. Bezprawne wykonywanie działalności w zakresie dystrybucji ubezpieczeń}

Do istoty przestępstwa bezprawnego wykonywania działalności w zakresie dystrybucji ubezpieczeń (art. 89 ust. 1 DUU) należy wykonywanie:

1. działalności agencyjnej z naruszeniem wymogów w zakresie podejmowania tej działalności, określonych w ustawie;

2. czynności agencyjnych, nie będąc do tego upoważnionym;

3. działalności brokerskiej w zakresie ubezpieczeń lub w zakresie reasekuracji bez wymaganego zezwolenia;

4. czynności brokerskich w zakresie ubezpieczeń lub reasekuracji, nie będąc do tego upoważnionym.

Ad 1 i 2

Czynności agencyjne, zgodnie z przepisem art. 4 ust. 3 DUU, to czynności w zakresie dystrybucji ubezpieczeń, wykonywane w imieniu

obrotu oraz o spółkach publicznych (Dz.U. z 2018 r. poz. 512, z późn. zm.; dalej „ustawa o ofercie publicznej").

45 P. Ochman, op. cit., s. 167.

46 A także inne podmioty określone w art. 3 ustawy z dnia 28 października $2002 \mathrm{r}$. o odpowiedzialności podmiotów zbiorowych za czyny zabronione pod groźbą kary (Dz.U. z 2018 r., poz. 703 z późn. zm.; dalej „OPZU”).

47 Przykładowo można wskazać na przestępstwa: $z$ art. 430-440 ustawy o działalności ubezpieczeniowej czy też art. 99-101 ustawy o ofercie publicznej. 
lub na rzecz zakładu ubezpieczeń. Katalog tych czynności jest zawarty przepisie w art. 4 ust. 1-2 oraz 6-7 DUU ${ }^{48}$. Ustawodawca wyraźnie jednak określił, jakie aktywności nie są uważane za dystrybucję ubezpieczeń (art. 6 DUU) ${ }^{49}$. Czynności agencyjne mogą być wykonywane wyłącznie przez osobę fizyczną, która spełnia łącznie następujące warunki: pełna zdolność do czynności prawnych, niekaralność ${ }^{50}$, rękojmia należytego wykonywania czynności agencyjnych, wykształcenie co najmniej średnie lub średnie branżowe, zdany egzamin. Warto wskazać, że warunkiem sine qua non wykonywania czynności agencyjnych jest wpis do rejestru agentów. W konsekwencji należy uznać, że brak takiego wpisu lub też

48 Dystrybucja ubezpieczeń oznacza działalność wykonywaną wyłącznie przez dystrybutora ubezpieczeń, polegającą na: 1 . doradzaniu, proponowaniu lub wykonywaniu innych czynności przygotowawczych zmierzających do zawarcia umów ubezpieczenia lub umów gwarancji ubezpieczeniowych; 2. zawieraniu umów ubezpieczenia lub umów gwarancji ubezpieczeniowych w imieniu zakładu ubezpieczeń, w imieniu lub na rzecz klienta albo bezpośrednio przez zakład ubezpieczeń; 3. udzielaniu pomocy przez pośrednika ubezpieczeniowego $\mathrm{w}$ administrowaniu umowami ubezpieczenia lub umowami gwarancji ubezpieczeniowych i ich wykonywaniu, także w sprawach o odszkodowanie lub świadczenie. Dystrybucja ubezpieczeń polega również na udzielaniu informacji dotyczących jednej lub większej liczby umów ubezpieczenia lub umów gwarancji ubezpieczeniowych na podstawie kryteriów wybranych przez klienta za pośrednictwem stron internetowych lub innych mediów oraz opracowywaniu rankingu produktów ubezpieczeniowych, obejmującego porównanie cen i produktów lub składek z tytułu umowy ubezpieczenia lub umowy gwarancji ubezpieczeniowej, w przypadku gdy klient jest w stanie pośrednio lub bezpośrednio zawrzeć umowę ubezpieczenia lub umowę gwarancji ubezpieczeniowej za pośrednictwem stron internetowych lub innych mediów. Dystrybucja ubezpieczeń polega również na organizowaniu i nadzorowaniu czynności agencyjnych $\mathrm{u}$ agenta ubezpieczeniowego lub agenta oferującego ubezpieczenia uzupełniające oraz czynności brokerskich w zakresie ubezpieczeń u brokera ubezpieczeniowego. Dystrybucję ubezpieczeń w zakresie grupy 3 działu I załącznika do ustawy o działalności ubezpieczeniowej i reasekuracyjnej może wykonywać wyłącznie agent ubezpieczeniowy, broker ubezpieczeniowy lub zakład ubezpieczeń.

49 Porównując zakres definicji czynności agencyjnych na gruncie ustawy o dystrybucji ubezpieczeń w relacji do ustawy o pośrednictwie ubezpieczeniowym, można zauważyć, iż katalog czynności agencyjnych został poszerzony o czynności związane $\mathrm{z}$ wypłatą świadczeń.

50 Brak prawomocnego skazania został ograniczony do umyślnych przestępstw skarbowych oraz przeciwko: życiu i zdrowiu, wymiarowi sprawiedliwości, ochronie informacji, wiarygodności dokumentów, mieniu, obrotowi gospodarczemu oraz obrotowi pieniędzmi i papierami wartościowymi. 
odpadnięcie którejkolwiek z przesłanek wykonywania czynności agencyjnych (na przykład prawomocne skazanie za przestępstwo oszustwa) powoduje, iż czynności agencyjne wykonywane są przez osobę niebędącą do tego upoważnioną w rozumieniu przepisu art. 89 ust. 1 pkt 2 DUU.

Nieco inaczej przedstawia się sytuacja w odniesieniu do kryminalizacji bezprawnego wykonywania działalności agencyjnej. Ustawa o dystrybucji ubezpieczeń, w przeciwieństwie do ustawy o pośrednictwie ubezpieczeniowym, wprost nie definiuje tego terminu ${ }^{51}$. Niemniej jednak na gruncie DUU za działalność agencyjną należy uznać również wykonywanie czynności ubezpieczeniowych przez agenta ubezpieczeniowego lub agenta oferującego ubezpieczenia uzupełniające. Wniosek taki, wyprowadzany z treści przepisu art. 4 ust. 3 DUU, koresponduje zresztą z ujęciem działalności agencyjnej jako „procesu ekonomicznego polegającego na aktywności usługowo-gospodarczej w dziedzinie pośrednictwa ubezpieczeniowego, obejmującego różnego rodzaju czynności faktyczne i prawne (agencyjne), przy czym osoba uprawniona do prowadzenia takiej działalności (agent) nie musi tychże czynności wykonywać osobiście" 52 . W konsekwencji działalność agencyjna powinna być utożsamiana z zarobkową i zorganizowaną działalnością agenta ubezpieczeniowego. Jednak ze względu na konieczność ścisłej wykładni przepisów prawa karnego powstaje wątpliwość, czy przepis art. 89 ust. 1 pkt 1 DUU kryminalizuje naruszenia wymogów wyłącznie w zakresie podejmowania działalności agencyjnej, czy może również działalności agenta. Wydaje się, że z uwagi na stosunkowo zagmatwaną konstrukcję „działalności agencyjnej” właśnie bardziej chodzi o warunki, które muszą spełniać agenci ubezpieczeniowi oraz agenci oferujący ubezpieczenia uzupełniające. Jest bowiem oczywiste, że podjęcie działalności agencyjnej (która może być wykonywana przez agentów) wbrew tym warunkom będzie stanowić naruszenie wymogów w zakresie podejmo-

51 Warto jednak podkreślić, że definicja ta daleka była od precyzji. Niestety również w wypowiedziach komentarzowych do przepisu karnego art. 47 PUU nie podejmowano prób dokonania wyraźnej delimitacji w tym zakresie, pomimo że termin ten ma zasadnicze znaczenie dla prawidłowej wykładni ustawowych znamion przestępstwa tam stypizowanego.

52 P. Sury, Praktyka bancassurance a przepisy karne ustawy o pośrednictwie ubezpieczeniowym, „Prokuratura i Prawo” 2014, nr 10, s. 108. 
wania tej działalności, określonych w ustawie. W konsekwencji agenci ubezpieczeniowi oraz agenci oferujący ubezpieczenia uzupełniające, będący osobami fizycznymi, muszą również spełniać warunki stawiane osobom wykonującym czynności agencyjne. W wypadku agentów ubezpieczeniowych oraz agentów oferujących ubezpieczenia uzupełniające będących spółkami osobowymi warunki takie muszą spełniać wspólnicy tych spółek, o ile są osobami fizycznymi, natomiast gdy wspólnikami są osoby prawne - co najmniej połowa ich członków zarządu, a w wypadku agentów ubezpieczeniowych oraz agentów oferujących ubezpieczenia uzupełniające będących osobami prawnymi — co najmniej połowa ich członków zarządu. Ponadto agenci niebędący osobami fizycznymi mogą wykonywać działalność agencyjną, jeżeli ich akcjonariat (udziałowcy) oraz istnienie bliskich powiązań z innymi podmiotami nie uniemożliwiają organowi nadzoru skutecznego sprawowania nadzoru. Agentem ubezpieczeniowym ani agentem oferującym ubezpieczenia uzupełniające nie może być przedsiębiorca prawomocnie pozbawiony prawa prowadzenia działalności gospodarczej zgodnie z art. 373 lub art. 374 ustawy z dnia 28 lutego 2003 r. - Prawo upadłościowe ${ }^{53}$. Naruszeniem wymogów prowadzenia działalności agencyjnej może być także, przykładowo, wykonywanie działalności agencyjnej na terytorium Rzeczypospolitej Polskiej przez podmiot mający siedzibę lub miejsce zamieszkania w innym niż Rzeczpospolita Polska państwie członkowskim Unii Europejskiej pomimo nieotrzymania przez organ nadzoru od właściwego organu państwa członkowskiego Unii Europejskiej odpowiednich danych i informacji (art. 43 DUU). Wydaje się jednak, że w świetle zaprezentowanych ustaleń bardziej prawidłowe i precyzyjne byłoby wskazanie w przepisie art. 89 ust. 1 pkt 1 DUU, że chodzi o działalność agenta wykonywaną z naruszeniem wymogów w zakresie jej podejmowania, określonych w ustawie.

\section{Ad 3 i 4}

Kryminalizacji, na podstawie przepisu art. 89 ust. 1 pkt 4 DUU, podlega wykonywanie czynności brokerskich w zakresie ubezpieczeń lub reasekuracji. Ustawodawca nie posługuje się jednak terminem „czynności brokerskie w zakresie ubezpieczeń lub reasekuracji”, lecz

53 Dz.U. z 2017 r. poz. 2344; dalej „Prawo upadłościowe”. 
odrębnie „czynności brokerskie w zakresie ubezpieczeń” oraz „czynności brokerskie w zakresie reasekuracji”. Czynności brokerskie w zakresie ubezpieczeń to, zgodnie z przepisem art. 4 ust. 4 DUU, czynności w zakresie dystrybucji ubezpieczeń w imieniu lub na rzecz klienta, dokonywane przez brokera ubezpieczeniowego w zakresie prowadzonej działalności brokerskiej. Katalog tych czynności zawarty jest przepisie w art. 4 ust. 1-2 oraz 6-7 DUU. Z kolei czynności brokerskie w zakresie reasekuracji to, zgodnie z przepisem art. 5 ust. 2 DUU, czynności w zakresie dystrybucji reasekuracji w imieniu lub na rzecz zakładu ubezpieczeń albo zakładu reasekuracji, wykonywane przez brokera reasekuracyjnego w ramach prowadzonej działalności brokerskiej. Katalog tych czynności zawarty jest przepisie w art. 5 ust. 1 i 4 DUU $^{54}$. Podobnie jak w odniesieniu do wyłączeń w zakresie dystrybucji ubezpieczeń ustawodawca wyraźnie określił, jakie aktywności nie są uważane za dystrybucję reasekuracji (art. 6 DUU) ${ }^{55}$. Czynności brokerskie w zakresie ubezpie-

54 Dystrybucja reasekuracji oznacza działalność wykonywaną wyłącznie przez dystrybutora reasekuracji, polegającą na: 1. doradzaniu, proponowaniu lub wykonywaniu innych czynności przygotowawczych zmierzających do zawarcia umów reasekuracji; 2. zawieraniu umów reasekuracji w imieniu zakładu ubezpieczeń lub zakładu reasekuracji albo bezpośrednio przez zakład ubezpieczeń lub zakład reasekuracji; 3. udzielaniu pomocy w administrowaniu umowami reasekuracji i ich wykonywaniu. Dystrybucja reasekuracji polega również na organizowaniu i nadzorowaniu czynności brokerskich w zakresie reasekuracji u brokera reasekuracyjnego.

55 Za dystrybucję ubezpieczeń ani za dystrybucję reasekuracji nie uznaje się: 1. okazjonalnego dostarczania klientowi informacji w związku z prowadzoną przez przedsiębiorcę działalnością gospodarczą inną niż działalność w zakresie dystrybucji ubezpieczeń lub dystrybucji reasekuracji, w przypadku gdy: a) przedsiębiorca nie podejmuje dodatkowych działań mających pomóc w zawarciu lub wykonywaniu umowy ubezpieczenia lub umowy gwarancji ubezpieczeniowej lub b) celem tej działalności nie jest pomoc w zawarciu lub wykonywaniu umowy reasekuracji; 2. obsługi roszczeń kierowanych do zakładu ubezpieczeń lub zakładu reasekuracji, wyceny szkód i sporządzania ekspertyz związanych z tymi szkodami; 3. przekazywania agentom ubezpieczeniowym, brokerom ubezpieczeniowym, brokerom reasekuracyjnym, zakładom ubezpieczeń lub zakładom reasekuracji danych i informacji na temat potencjalnych klientów, jeżeli przedsiębiorca nie podejmuje dodatkowych działań mających pomóc w zawarciu umowy ubezpieczenia, umowy gwarancji ubezpieczeniowej lub umowy reasekuracji; 4. przekazywania potencjalnym klientom informacji na temat produktów ubezpieczeniowych lub reasekuracyjnych, agenta ubezpieczeniowego, brokera ubezpieczeniowego, brokera reasekuracyjnego, zakładu ubezpieczeń lub zakładu reasekuracji, jeżeli przedsiębiorca nie 
czeń lub w zakresie reasekuracji mogą być wykonywane przez brokera ubezpieczeniowego i brokera reasekuracyjnego wyłącznie przy pomocy osób, które: mają pełna zdolność do czynności prawnych, są niekara$n \mathrm{e}^{56}$, dają rękojmię należytego wykonywania działalności brokerskiej odpowiednio w zakresie ubezpieczeń lub reasekuracji, mają co najmniej wykształcenie średnie lub średnie branżowe, zdały egzamin przed Komisją Egzaminacyjną dla Brokerów Ubezpieczeniowych i Reasekuracyjnych odpowiednio do zakresu działalności albo uzyskały odpowiednie zwolnienie z egzaminu. Warunkiem sine qua non wykonywania czynności brokerskich jest wpis do rejestru brokerów. W konsekwencji należy uznać, że brak takiego wpisu lub też odpadnięcie którejkolwiek z przesłanek wykonywania czynności agencyjnych (na przykład prawomocne skazanie za przestępstwo oszustwa) powoduje, iż czynności brokerskie wykonywane są przez osobę niebędącą do tego upoważnioną w rozumieniu przepisu art. 89 ust. 1 pkt 4 DUU.

Warunkiem prowadzenia działalności brokerskiej jest posiadanie indywidualnego aktu administracyjnego, wydawanego przez Komisję Nadzoru Finansowego. Może on przybrać postać zezwolenia na wykonywanie działalności brokerskiej w zakresie ubezpieczeń albo zezwolenie na wykonywanie działalności brokerskiej w zakresie reasekuracji (ten sam podmiot może jednak posiadać oba zezwolenia). Zezwolenie wydawane jest na wniosek osoby fizycznej lub osoby prawnej. Działalności brokerskiej nie może zatem wykonywać jednostka organizacyjna niemająca osobowości prawnej ${ }^{57}$. W wypadku gdy podmiotem zezwolenia jest osoba fizyczna, musi ona spełnić warunki niezbędne dla osób

podejmuje dodatkowych działań mających pomóc w zawarciu umowy ubezpieczenia, umowy gwarancji ubezpieczeniowej lub umowy reasekuracji.

56 Brak prawomocnego skazania ograniczony został do umyślnych przestępstw skarbowych oraz przeciwko: życiu i zdrowiu, wymiarowi sprawiedliwości, ochronie informacji, wiarygodności dokumentów, mieniu, obrotowi gospodarczemu oraz obrotowi pieniędzmi i papierami wartościowymi.

57 Warto jednak wskazać, że działalność taka wykonywana jest w formie na przykład spółki osobowej, z punktu widzenia możliwości popełnienia przestępstwa jest bez znaczenia, gdyż posłużenie się przez ustawodawcę klauzulą odpowiedzialności zastępczej powoduje, że kryminalizacji podlega wyłącznie bezprawne prowadzenie działalności brokerskiej przez osoby fizyczne we własnym imieniu bądź przez osoby fizyczne działające w imieniu osoby prawnej. 
wykonujących czynności brokerskie, a także ponadto mieć co najmniej dwuletnie doświadczenie zawodowe odpowiednio w zakresie ubezpieczeń lub reasekuracji, zdobyte w okresie 8 lat bezpośrednio poprzedzających złożenie wniosku o uzyskanie zezwolenia na wykonywanie działalności brokerskiej, a także zawrzeć umowę ubezpieczenia odpowiedzialności cywilnej z tytułu wykonywania działalności brokerskiej odpowiednio w zakresie ubezpieczeń lub reasekuracji. Jeżeli podmiotem zezwolenia jest osoba prawna, musi ona zawrzeć umowę ubezpieczenia odpowiedzialności cywilnej z tytułu wykonywania działalności brokerskiej odpowiednio w zakresie ubezpieczeń lub reasekuracji, członkowie jej zarządu muszą mieć pełną zdolność do czynności prawnych, legitymować się niekaralnością ${ }^{58}$, dawać rękojmię należytego wykonywania działalności brokerskiej oraz mieć co najmniej średnie wykształcenie lub średnie branżowe, a nadto co najmniej połowa z nich musi zdać egzamin przed Komisją Egzaminacyjną dla Brokerów Ubezpieczeniowych i Reasekuracyjnych oraz mieć co najmniej dwuletnie doświadczenie zawodowe albo uzyskać odpowiednie zwolnienie z egzaminu, a ponadto akcjonariat (udziałowcy) takiej osoby prawnej oraz istnienie bliskich powiązań z innymi podmiotami nie mogą uniemożliwiać skutecznego sprawowania nadzoru przez Komisję Nadzoru Finansowego. Brokerem ubezpieczeniowym ani brokerem reasekuracyjnym nie może być przedsiębiorca prawomocnie pozbawiony prawa prowadzenia działalności gospodarczej zgodnie z art. 373 lub art. 374 Prawa upadłościowego. Brak zezwolenia właściwemu podmiotowi na wykonywanie działalności brokerskiej w zakresie ubezpieczeń lub zezwolenia na wykonywanie działalności brokerskiej w zakresie reasekuracji może realizować znamiona przestępstwa $\mathrm{z}$ art. 89 ust. 1 pkt 3 DUU.

Warto wskazać, że „wykonywanie” inkryminowanych aktywności wskazuje na pewną względnie stałą i zorganizowaną działalność. W konsekwencji przypisanie odpowiedzialności karnej z tytułu przestępstw z art. 89 ust. 1 DUU nie będzie możliwe w wypadku incydentalnego, jednorazowego lub dorywczego przedsiębrania działalności składającej się na określoną formę dystrybucji ubezpieczeń ${ }^{59}$.

$58 \mathrm{~W}$ zakresie tożsamym z osobami wykonującymi czynności brokerskie.

59 Zob. Z. Sienkiewicz op. cit., s. 503. 
e. Bezprawne używanie określeń wskazujących na wykonywanie dystrybucji ubezpieczeń (reasekuracji)

Przestępstwo bezprawnego używania określeń wskazujących na wykonywanie dystrybucji ubezpieczeń lub dystrybucji reasekuracji polega na ich używaniu przez osobę niebędącą dystrybutorem ubezpieczeń, dystrybutorem reasekuracji ani podmiotem transgranicznie wykonującym działalność agencyjną lub brokerską w firmie, reklamie lub do oznaczania własnej działalności gospodarczej. Zakaz używania określeń wskazujących na wykonywanie działalności agencyjnej lub czynności agencyjnych przewiduje przepis art. 24 DUU. Z kolei w odniesieniu do używania określeń wskazujących na wykonywanie działalności brokerskiej w zakresie ubezpieczeń lub reasekuracji płaszczyznę bezprawności statuuje przepis art. 33 DUU. Przedstawione przepisy fundują tak zwaną zasadę prawdziwości, wyrażającą się w nakazie zgodności brzmienia określeń wskazujących na wykonywanie danej działalności ze statusem prawnym i faktycznym podmiotu używającego tego oznaczenia ${ }^{60}$. W przeciwieństwie jednak do przepisu karnego kryminalizującego wskazany już stan rzeczy (art. 90 DUU), bezprawność używania stosownych oznaczeń odnosi się do oznaczenia każdej działalności, a nie wyłącznie własnej działalności gospodarczej (zawężenie zakresu kryminalizacji). Określenia wskazujące na wykonywanie dystrybucji ubezpieczeń to przykładowo: „zakład ubezpieczeń”, ,,agent ubezpieczeniowy”, ,agent oferujący ubezpieczenia uzupełniające" 61 . Z kolei na wykonywanie dystrybucji reasekuracji może wskazywać użycie określenia „broker reasekuracyjny”. Używanie przedmiotowych określeń „,w nazwie” danego podmiotu polega na posługiwaniu się nimi w celu oznaczenia przedsiębiorcy, a zatem poprzez ich umieszczenie na przykład obok formy prawnoorganizacyjnej podmiotu oraz innego określenia jego nazwy. Z kolei używanie oznaczeń do oznaczania własnej działalności gospodarczej ma szerszy zakres, gdyż odnosi się do posługiwania się przedmiotowymi określeniami w celu oznaczenia funkcjonowania (zespołu działań) określonego podmiotu czy też jego struktury organizacyjnej (na przykład oznaczenie przedsiębiorstwa) niekoniecznie wyodrębnionej prawnie. Działalność,

\footnotetext{
60 Zob. także E. Wieczorek, op. cit., s. 1114 i 1171,

61 Komentarz do art. 90 ustawy o dystrybucji ubezpieczeń.
} 
w ramach której będzie następować wykorzystywanie przedmiotowych określeń, musi stanowić działalność gospodarczą ${ }^{62}$. Natomiast używanie wskazanych określeń w reklamie odnosi się do posługiwania się nimi w działaniach zmierzających do pozyskania potencjalnych klientów. Forma takich działań jest irrelewantna ${ }^{63}$, dlatego też przedmiotowe działania mogą następować za pośrednictwem radia, telewizji, sieci Internet, prasy, ulotek itd.

\section{f. Pozostałe zagadnienia}

Przestępstwa z ustawy o dystrybucji ubezpieczeń, podobnie zresztą jak ustawy o pośrednictwie ubezpieczeniowym, są przestępstwami umyślnymi. Mogą być one popełnione w postaci zamiaru zarówno bezpośredniego, jak i ewentualnego ${ }^{64}$.

Przestępstwa z art. 89 zagrożone są sankcją alternatywną w postaci kary grzywny, kary ograniczenia wolności oraz kary pozbawienia wolności do lat 2. Z kolei przestępstwa stypizowane art. 89 zagrożone są sankcją alternatywną w postaci kary grzywny, kary ograniczenia wolności albo kary pozbawienia wolności do roku. Takie ukształtowanie modelu sankcji karnej daje podstawy do szerokiego stosowania wobec sprawców przestępstw z ustawy o dystrybucji ubezpieczeń kar wolnościowych. Należy jednak zwrócić uwagę na brak spójności kar za te przestępstwa w relacji do innych, pokrewnych dziedzinowo typów przestępstw występujących w ustawodawstwie rynku finansowego ${ }^{65}$.

62 Zgodnie z przepisem art. 3 ustawy z dnia 6 marca 2018 r. - Prawo przedsiębiorców (Dz.U. z 2018 r. poz. 646), działalnością gospodarczą jest zorganizowana działalność zarobkowa, wykonywana we własnym imieniu i w sposób ciągły.

63 Por. przepis art. 2 lit. a dyrektywy 2006/114/WE Parlamentu Europejskiego i Rady z dnia 12 grudnia 2006 r. dotycząca reklamy wprowadzającej w błąd i reklamy porównawczej (Dz.Urz. UE Seria L z 2006 r., Nr 376), który wśród cech reklamy wskazuje jej nakierowanie na wspieranie zbytu oraz dowolność formy.

64 Tak też E. Hryniewicz, op. cit., s. 322.

65 Zob. szerzej P. Ochman, Uwagi na temat sankcji w pozakodeksowym prawie karnym gospodarczym (na przykładzie ustawodawstwa karnego rynku finansowego), [w:] Współczesne przekształcenia sankcji karnych: zagadnienia teorii, wykładni i praktyki stosowania, red. P. Góralski, A. Muszyńska, Warszawa 2018, s. 361-377. 


\section{Podsumowanie}

Przepisy karne ustawy o dystrybucji ubezpieczeń stanowią jeden $\mathrm{z}$ instrumentów karnoprawnej ochrony rynku ubezpieczeniowego w Polsce. O jego skuteczności będzie można się dopiero przekonać po wejściu omawianej ustawy w życie, poprzez obserwację praktyki orzeczniczej. Warto jednak wskazać, że praktyka ta na gruncie przepisów karnych ustawy o pośrednictwie ubezpieczeniowym nie była imponująca. W latach 2008-2016 za przestępstwa z ustawy o pośrednictwie ubezpieczeniowym skazywano po jednej osobie dorosłej: 2009 rok (art. 47 ust. 1 pkt 1 PUU), 2012 rok (art. 47 ust. 1 pkt 2 PUU), 2014 rok (art. 47 ust. 1 pkt 2 PUU) i 2016 rok (art. 47 ust. 1 pkt 1 PUU) ${ }^{66}$. Niestety, ustawa o dystrybucji ubezpieczeń powiela mankamenty swojej poprzedniczki. Można zaliczyć do nich zwłaszcza: wadliwość oraz niecelowość funkcjonowania klauzul odpowiedzialności zastępczej, brak odpowiedzialności podmiotów zbiorowych za czyny zabronione pod groźbą kary, nieprawidłowe, skrótowe posłużenie się w przepisie art. 89 ust. 1 pkt 3 DUU terminem „,czynności brokerskie w zakresie ubezpieczeń lub reasekuracji” zamiast „czynności brokerskie w zakresie ubezpieczeń lub czynności brokerskie w zakresie reasekuracji”, nieprawidłowe użycie spójnika koniunkcji w przepisie art. 89 ust. 2 DUU zamiast spójnika alternatywy łącznej, a także brak spójności w zakresie karania w relacji do przepisów karnych pokrewnych ustaw dziedzinowych. Niektóre z mankamentów można co prawda usunąć drogą interpretacji, jednakże biorąc pod uwagę, iż prawo karne gospodarcze również stanowi „prawo granic”, granice te powinny być przez ustawodawcę wytyczone jasno i precyzyjnie.

66 Prawomocnie skazani dorośli wg rodzajów przestępstw i wymiaru kary w l. 20082016, https://isws.ms.gov.pl/pl/baza-statystyczna/opracowania-wieloletnie/download,2853,40.html (dostęp: 5.06.2018). 


\title{
Criminalization of insurance intermediation in criminal economic law
}

\begin{abstract}
Summary
The subject of the article is the analysis of criminal laws criminalizing insurance intermediation in Poland. This is an issue that falls under the dogmatic considerations of criminal economic law in the aspect of protecting the statics of economic turnover, i.e. its basic structures and institutions. The evolution of the criminalization of this sector of the insurance market, the genesis of current criminal law regulations as well as critical remarks to the latest penal provisions of the Insurance Distribution Act will be presented. The analyzes will be the basis for presenting de lege lata's comments and the de lege ferenda proposal.
\end{abstract}

Keywords: insurance intermediation, economic law, criminal economic law. 